\title{
ANALISIS PERMINTAAN BUAH SEMANGKA DI KOTA PALANGKA RAYA
}

\author{
ANALYSIS OF WATERMELON DEMAND \\ IN THE PALANGKA RAYA CITY
}

\author{
${ }^{1}$ Julkifli, ${ }^{2}$ Maleha, ${ }^{3}$ Rajudinnor \\ ${ }^{1}$ Alumnus Program Studi Agribisnis Fakultas Pertanian Universitas Palangka Raya \\ ${ }^{2,3}$ Staf Pengajar Program Studi Agribisnis Fakultas Pertanian Universitas Palangka Raya \\ email:malehaplk@gmail.com
}

\begin{abstract}
ABSTRAK
Penelitian ini bertujuan untuk mengetahui faktor-faktor yang mempengaruhi permintaan semangka di Kota Palangka Raya. Data yang digunakan adalah data sekunder dari 2002-2016. Metode analisis data adalah analisis regresi linier berganda dengan menggunakan alat SPPS24. Hasil penelitian menunjukkan bahwa koefisien determinasi adalah 0,936, artinya 93,6\% dari permintaan semangka di Kota Palangka Raya dipengaruhi oleh harga semangka, harga buah pepaya, harga pisang, harga per kapita, dan penduduk. Hasil uji F menunjukkan bahwa F hitung $=26,109$ lebih besar dari nilai Ftabel $=6,06$ pada tingkat kepercayaan 99\%, sehingga faktor-faktor yang diuji bersama memiliki pengaruh yang signifikan terhadap permintaan semangka di Kota Palangka Raya yang berada pada tingkat kepercayaan 90\%-99\%. Sementara faktor populasi tidak berpengaruh pada tingkat kepercayaan $95 \%$.
\end{abstract}

Kata kunci: Analisis permintaan, semangka

\section{ABSTRACT}

This study aims to determine the factors that influence the demand for watermelon in the City of Palangka Raya. The data used are secondary data from 2002-2016. Data analysis method is multiple linear regression analysis using SPPS-24 tool. The results showed that the coefficient of determination was 0.936, meaning 93.6\% of the demand for watermelon in Palangka Raya City was influenced by the price of watermelon, the price of papaya fruit, the price of bananas, per capita income and population. The results of the $F$ test show that the calculated $F=26.109$ is greater than the Ftable value $=6.06$ at the $99 \%$ confidence level, so that the factors tested together have a significant effect on the demand for watermelon in the City of Palangka Raya that is at the level of trust of 90\%-99\%. While the population factor has no effect on the $95 \%$ confidence level.

Keywords: Demand analysis, watermelon

\section{PENDAHULUAN}

\section{Latar Belakang}

Salah satu komoditas buah-buahan yang berkembang di Indonesia adalah semangka. Menurut Baga (2008), semangka (Citrulluslanatus) merupakan komoditas buah-buahan berasal dari Afrika yang kemudian dikembangkan di Indonesia. Persamaan iklim tropis antara Afrika dan Indonesia menjadikan semangka dapat berkembang dengan baik. Tanaman semangka dikonsumsi segar buahnya atau dibuat produk olahan untuk memenuhi kebutuhan pangan. Buah semangka hingga saat ini hanya disajikan 
secara segar sebagai buah meja. Buah semangka mudah diperoleh di pasar-pasar besar, supermarket, dan pasar kios. Semangka menjadi salah satu komoditas buah-buahan unggulan yang punya pasar di luar negeri selain manggis, mangga, dan melon. Sejak tahun 2016 permintaan semangka berasal dari sejumlah negara di antaranya Thailand, Malaysia, Cina dan Jepang (Purnamasari, 2018).

Masuknya bibit-bibit semangka impor mempunyai daya tarik yang kuat, sebab buah semangka tersebut mampu merebut pasaran sejajar dengan buah- buahan jenis lain yang sebagian masih di impor dari luar negeri. Buah semangka yang berkualitas baik telah banyak dipasarkan di supermarket di kota-kota besar dan yang menjadi pelanggannya adalah masyarakat golongan ekonomi menengah ke atas. Dengan kenyataan yang demikian menjadikan permintaan pasar buah semangka semakin meningkat. Terlebih lagi pada saat hasil panen buah dari daerah-daerah penghasilnya menurun jumlahnya, sehingga harganya pun melonjak beberapa kali lipat (Jaya, 2016).

Tabel 1. Petumbuhan Produktivitas Buah-buahan di Kalimantan Tengah Tahun 2014-2016

\begin{tabular}{|c|c|c|c|c|c|}
\hline \multirow[t]{2}{*}{ No. } & \multirow[t]{2}{*}{ Komoditas } & \multicolumn{3}{|c|}{$\begin{array}{c}\text { Produktivitas } \\
(\mathrm{Kw} / \mathrm{Ha})\end{array}$} & \multirow{2}{*}{$\begin{array}{c}\text { Pertumbuhan } \\
(\%) \\
2015 \text { ke } 2016\end{array}$} \\
\hline & & 2014 & 2015 & 2016 & \\
\hline 1. & Blewah & 4,00 & 30,75 & 0,00 & $-100,00$ \\
\hline 2. & Melon & 17,31 & 27,80 & 80,02 & 187,84 \\
\hline 3. & Semangka & 48,97 & 34,79 & 55,79 & 60,36 \\
\hline & Pepaya & 0,69 & 0,70 & 0,42 & $-40,00$ \\
\hline 5. & Pisang & 0,42 & 0,41 & 0,61 & 48,78 \\
\hline
\end{tabular}

Sumber: Badan Pusat Statistik Kalimantan Tengah, 2017.

Pada Tabel 1, dapat dilihat bahwa buah melon, semangka dan pisang menunjukkan produktivitas yang setiap tahunnya meningkat. Peningkatan tersebut dapat dibuktikan dari pertumbuhan produktivitas buah melon tahun 2015 ke 2016 sebesar $187,84 \%$, semangka $60,36 \%$ dan pisang $48,78 \%$. Pada buah blewah tidak mengalami pertumbuhan dikarenakan pada tahun 2016 tidak berproduksi, padahal jika dilihat tahun sebelumnya mengalami peningkatan produktivitas dari $4 \mathrm{Kw} / \mathrm{Ha}$ menjadi 30,75 $\mathrm{Kw} / \mathrm{Ha}$ pada tahun 2015, sedangkan buah pepaya terjadi penurunan produktivitas pada tahun 2016 sehingga pertumbuhannya menurun sebesar $40,00 \%$.

Tabel 2. Luas Panen, Produksi dan Produktivitas Semangka Menurut Kabupaten /Kota Tahun 2016

\begin{tabular}{|c|c|c|c|c|}
\hline No. & Kabupaten/Kota & $\begin{array}{c}\text { Luas Panen } \\
(\mathrm{Ha})\end{array}$ & $\begin{array}{c}\text { Produksi } \\
(\mathrm{Kw})\end{array}$ & $\begin{array}{c}\text { Produktivitas } \\
(\mathrm{Kw} / \mathrm{Ha})\end{array}$ \\
\hline & Kotawaringin Barat & 114 & 6.590 & 57,81 \\
\hline 2. & Kotawaringin Timur & 37 & 4.678 & 126,43 \\
\hline 3. & Kapuas & 294 & 17.516 & 59,58 \\
\hline 4. & Barito Selatan & 8 & 235 & 29,58 \\
\hline & Barito Utara & 0 & 0 & 0 \\
\hline & Sukamara & 5 & 30 & 6,00 \\
\hline & Lamandau & 74 & 8.488 & 114,70 \\
\hline & Seruyan & 46 & 1.154 & 25,09 \\
\hline 9. & Katingan & 15 & 235 & 4,25 \\
\hline 10. & Pulang Pisau & 158 & 671 & 4,25 \\
\hline
\end{tabular}




$\begin{array}{lrrr}\text { 11. Gunung Mas } & 2 & 32 & 16,00 \\ \text { 12. Barito Timur } & 0 & 0 & 0 \\ \text { 13. Murung Raya } & 0 & 0 & 0 \\ \text { 14. Palangka Raya } & 29 & 4.001 & 137,97 \\ \text { Kalimantan Tengah } & 782 & 43.630 & 55,79\end{array}$

Sumber: Badan Pusat Statistik Kalimantan Tengah, 2017.

Berdasarkan Tabel 2, diketahui bahwa pada sisi produktivitas buah semangka yang paling tertinggi adalah di Kota Palang Raya, meskipun luas wilayah panen hanya sebesar $29 \mathrm{Ha}$, namun buah semangka di Kota Palangka Raya mampu memproduksi sebesar $4.001 \mathrm{Kw}$ dengan jumlah produktivitas sebanyak 137,97 $\mathrm{Kw} / \mathrm{Ha}$.

Produksi buah semangka di Kota Palangka Raya selalu berfluktuasi dalam kurun waktu lima tahun terakhir (20122016). Produksi buah semangka di Kota Palangka Raya selama lima tahun terakhir dapat dilihat pada Tabel 3.

Tabel 3. Luas Panen, Produksi dan Produktivitas Semangka di Kota Palangka Raya Tahun 2012-2016

\begin{tabular}{ccccc}
\hline No. & Tahun & $\begin{array}{c}\text { Luas Panen } \\
(\mathrm{Ha})\end{array}$ & $\begin{array}{c}\text { Produksi } \\
(\mathrm{Kw})\end{array}$ & $\begin{array}{c}\text { Produktivitas } \\
(\mathrm{Kw} / \mathrm{Ha})\end{array}$ \\
\hline 1. & 2012 & 28 & 3.681 & 131,46 \\
2. & 2013 & 47 & 2.051 & 43,64 \\
3. & 2014 & 26 & 1.370 & 52,69 \\
4. & 2015 & 13 & 1.502 & 111,54 \\
5. & 2016 & 29 & 4.001 & 137,97 \\
\hline
\end{tabular}

Sumber: Badan Pusat Statistik Provinsi Kalimantan Tengah, 2017.

Berdasarkan Tabel 3, menunjukkan produksi buah semangka di Kota Palangka Raya dimana setiap tahunnya berbeda. Pada tahun 2012 produksi buah semangka cukup tinggi yaitu sebesar $3.681 \mathrm{Kw}$, namun ditahun selanjutnya 2012-2015 produksi buah semangka mengalami penurunan karena luas panen sedikit. Kembali ditahun 2016 produksi buah semangka mengalami kenaikan yaitu sebesar $4.001 \mathrm{Kw}$.

Tabel 4. Jumlah Permintaan Buah Semangka dan Jumlah Penduduk Kota Palangka Raya, Tahun 2012-2016

\begin{tabular}{cccc}
\hline No. & Tahun & $\begin{array}{c}\text { Permintaan Buah Semangaka } \\
(\mathrm{Kg})\end{array}$ & $\begin{array}{c}\text { Jumlah Penduduk } \\
(\text { Jiwa })\end{array}$ \\
\hline 1. & 2012 & $775.020,90$ & 236.355 \\
2. & 2013 & $758.038,80$ & 244.454 \\
3. & 2014 & $978.083,00$ & 252.105 \\
4. & 2015 & $955.834,30$ & 259.865 \\
5. & 2016 & $911.617,30$ & 267.757 \\
\hline
\end{tabular}

Sumber: Badan Pusat Statistik Kalimantan Tengah, 2017.

Berdasarakan Tabel 4, menunjukan permintaan buah semangka di Kota Palangka Raya, dimana setiap tahunnya berfluktasi sedangkan jumlah penduduk selalu meningkat. Pada tahun 2014 permintaan buah semangka sebesar
978.083,00 Kg dan pada tahun selanjutnya mengalami penurunan dimana pada tahun 2016 permintaan buah semangka turun sebesar 911.617,30 Kg.

Kota Palangka Raya adalah sebuah kota sekaligus merupakan ibu kota Provinsi 
Kalimantan Tengah. Memiliki luas wilayah $2.400 \mathrm{~km}^{2}$ yang terdiri atas 5 (lima) kecamatan, yaitu: Pahandut, Jekan Raya, Bukit Batu, Sebangau, dan Rakumpit. Palangka Raya merupakan kota dengan perkembangan ekonomi yang cukup pesat, sehingga mempengaruhi perilaku dan gaya hidup masyarakatnya. Baik untuk pemenuhan kebutuhan primer, sekunder, dan tersier. Dengan kondisi tersebut konsumsi untuk buah-buahan juga menjadi prioritas dalam memenuhi asupan gizi (Karyatmo, 2012). Sekarang ini keberadaan buah semangka khususnya di Kota Palangka Raya adalah salah satu buah yang merupakan primadona dikala musim kemarau. Banyak sekali petani mulai beralih menanam semangka pada musim kemarau. Benih semangka yang digunakan biasanya bisa didapatkan dari bijinya dengan cara disemai ke tanah dan tentunya benih semangka dengan kualitas terbaik dan pilihan (BPTP Kalimantan Tengah, 2018).

Tujuan penelitian ini untuk mengetahui faktor-faktor yang mempengaruhi permintaan buah semangka di Kota Palangka Raya.

\section{METODE PENELITIAN}

Pemilihan tempat penelitian dilakukan secara sengaja (porposive). Tempat penelitian ini adalah Kota Palangka Raya dengan pertimbangan bahwa Kota Palangka Raya merupakan salah satu daerah yang penduduknya sebagian besar bekerja pada instansi pemerintah maupun swasta sehingga kebutuhan akan konsumsi buah-buahan sangat besar dan mempunyai potensi untuk diteliti, selain itu dalam hal pengadaan buah semangka Kota Palangka Raya masih mendatangkan dari luar daerah.

Jenis data yang digunakan dalam penelitian ini adalah data sekunder, yaitu data yang diperoleh dari publikasi instansi terkait atau lembaga yang berhubungan dengan penelitian ini. Data sekunder yang digunakan dalam penelitian ini dari tahun 2002-2016 meliputi data permintaan buah semangka (Kg/Tahun), harga buah semangka ( $\mathrm{Rp} / \mathrm{Kg})$, harga buah pepaya $(\mathrm{Rp} / \mathrm{Kg})$, harga buah pisang $(\mathrm{Rp} / \mathrm{Kg})$, pendapatan perkapita (Rp/Kapita) dan jumlah penduduk (Jiwa) serta data pendukung lainnya.

Sumber data dalam penelitian ini, diperoleh dari Badan Pusat Statistik Provinsi Kalimantan Tengah, Dinas Perindustrian Perdagangan Provinsi Kalimantan Tengah, Dinas Ketahanan Pangan dan Pertanian Kota Palangka Raya.

Data dari hasil penelitian diolah dengan menggunakan tabulasi (tabel) sederhana yang sesuai dengan tujuan penelitian. Pengolahan data kuantitatif dilakukan dengan menggunakan komputer, sedangkan data kualitatif diuraikan lebih lanjut secara deskriptif.

Analisis data yang digunakan dalam penelitian ini adalah regresi linier berganda yang telah dilogaritmakan terlebih dahulu. Hal ini bertujuan untuk menghindari data yang tidak linier (terjadi non-linearitas) dengan menggunakan alat bantu SPSS 24. Untuk menjawab tujuan penelitian yaitu untuk mengetahui fungsi permintaan buah semangka pada tahun 2002-2016 di Kota Palangka Raya, maka dianalisis dengan fungsi produksi CobbDouglas. Secara matematis sebagai berikut:

$\mathrm{Y}=\mathrm{b}_{0}+\mathrm{X}_{1}{ }^{\mathrm{b} 1}+\mathrm{X}_{2}{ }^{\mathrm{b} 2}+\mathrm{X}_{3}{ }^{\mathrm{b} 3}+\mathrm{X}_{4}{ }^{\mathrm{b} 4}+\mathrm{X}_{5}{ }^{\mathrm{b} 5}+\mathrm{e}$

Untuk mempermudahkan penghitungan dan pendugaan terhadap persamaan tersebut di atas maka persamaan tersebut diubah menjadi bentuk logaritma natural (In), sehingga diperoleh sebagai berikut: In $Y=\operatorname{In} b_{0}+b_{1}$ In $X_{1}+b_{2}$ In $X_{2}+b_{3}$ In
$X_{3}+b_{4} \operatorname{In} X_{4}+b_{5}$ In $X_{5}+e$

Keterangan:

$\begin{aligned} \mathrm{Y}= & \begin{array}{l}\text { Permintaan buah semangka } \\ (\mathrm{Kg} / \text { Tahun })\end{array} \\ \mathrm{bo}= & \text { Nilai Konstanta } \\ \mathrm{b}_{1}-\mathrm{b}_{5}= & \text { Koefisien regresi } \\ \mathrm{X}_{1}= & \text { Harga buah semangka }(\mathrm{Rp} / \mathrm{Kg})\end{aligned}$




$$
\begin{aligned}
& \mathrm{X}_{2}=\text { Harga buah Pepaya }(\mathrm{Rp} / \mathrm{Kg}) \\
& \mathrm{X}_{3}=\operatorname{Harga} \text { buah Pisang }(\mathrm{Rp} / \mathrm{Kg}) \\
& \mathrm{X}_{4}=\text { Pendapatan perkapita }(\mathrm{Rp} / \mathrm{Jiwa}) \\
& \mathrm{X}_{5}=\text { Jumlah Penduduk (Jiwa) } \\
& \mathrm{e}
\end{aligned}
$$

\section{Uji Statistik}

1. Uji Koefisien determinasi $\left(\mathrm{R}^{2}\right)$ Koefisien determinasi $\left(\mathrm{R}^{2}\right)$ pada intinya mengukur seberapa jauh kemampuan model dalam menerangkan variasi variabel terikat (dependen). Nilai koefisien determinasi adalah antara 0 sampai dengan $1\left(0 \leq \mathrm{R}^{2} \leq 1\right)$. Semakin besar $\mathrm{R}^{2}$ (mendekati 1) semakin baik hasil regresi tersebut (semakin besar pengaruh variabel bebas terhadap variabel tak bebas), dan semakin mendekati 0 maka variabel bebas secara keseluruhan semakin kurang bisa menjelaskan variabel tak bebas. Koefisien determinasi $\left(\mathrm{R}^{2}\right)$ merupakan suatu nilai statistik yang dihitung dari data sampel. Koefisien ini menunjukan persentase variasi seluruh variabel terikat yang dapat dijelaskan oleh perubahan variabel bebas. Koefisien ini merupakan suatu ukuran sejauh mana variabel bebas dapat merubah variabel terikat dalam suatu hubungan. Nilai koefisien determinasi $\left(\mathrm{R}^{2}\right)$ berkisar antara $0 \leq \mathrm{R}^{2} \leq 1$. Dengan kriteria pengujiannya adalah $\mathrm{R}^{2}$ yang semakin tinggi (mendekati 1) menunjukan model yang terbentuk mampu menjelaskan keragaman dari variabel terikat.

\section{Uji F-Statistik}

Uji $F$ digunakan untuk menguji apakah secara statistik bahwa koefisien regresi dari variabel independen secara bersama-sama memberikan pengaruh yang bermakna dengan membandingkan nilai probabilitas (F-statistik) dengan $\mathrm{F}$ tabel, dengan ketentuan jika $\mathrm{F}$ statistik $>\mathrm{F}$ tabel maka $\mathrm{H}_{0}$ ditolak dan $\mathrm{H}_{\mathrm{a}}$ diterima berarti variabel independen berpengaruh signifikan terhadap variabel dependen secara bersama-sama. Artinya parameter $\mathrm{X}_{1}, \mathrm{X}_{2}$, $\mathrm{X}_{3}, \mathrm{X}_{4}$ dan $\mathrm{X}_{5}$ secara bersamaan di uji apakah memiliki signifikansi atau tidak.

Kriteria Pengujian:
Jika sig. $\mathrm{F} \leq 0,05$ maka $\mathrm{H}_{0}$ ditolak dan $\mathrm{H}_{\mathrm{a}}$ diterima.

Jika sig. $\mathrm{F}>0,05$ maka $\mathrm{H}_{0}$ diterima dan $\mathrm{H}_{\mathrm{a}}$ ditolak.

Jika $\mathrm{H}_{0}$ diterima artinya secara serempak $\mathrm{X}_{1}, \mathrm{X}_{2}, \mathrm{X}_{3}, \mathrm{X}_{4}$ dan $\mathrm{X}_{5}$ tidak berpengaruh nyata terhadap $\mathrm{Y}$ (permintaan buah semangka di Kota Palangka Raya).

Jika $\mathrm{H}_{\mathrm{a}}$ diterima artinya secara serempak $\mathrm{X}_{1}, \mathrm{X}_{2}, \mathrm{X}_{3}, \mathrm{X}_{4}$ dan $\mathrm{X}_{5}$ berpengaruh nyata terhadap $\mathrm{Y}$ (permintaan buah semangka di Kota Palangka Raya).

\section{Uji Parsial (Uji t Statistik)}

Uji $t$ adalah uji secara parsial pengaruh variabel independen terhadap variabel dependen digunakan untuk mengetahui apakah variabel bebas secara parsial atau masing-masing berpengaruh nyata atau tidak terhadap variabel terikat. Untuk menguji pengaruh masing-masing variabel penduga terhadap permintaan digunakan uji t dengan tingkat kepercayaan 95\%.

Kriteria Pengujian:

Jika sig. $\mathrm{t} \leq 0,05$ maka $\mathrm{H}_{0}$ ditolak dan $\mathrm{H}_{\mathrm{a}}$ diterima.

Jika sig. $\mathrm{t}>0,05$ maka $\mathrm{H}_{0}$ diterima dan $\mathrm{H}_{\mathrm{a}}$ ditolak.

Jika $\mathrm{H}_{0}$ diterima artinya secara parsial $\mathrm{X}_{1}$, $\mathrm{X}_{2}, \mathrm{X}_{3}, \mathrm{X}_{4}$ dan $\mathrm{X}_{5}$ tidak berpengaruh nyata terhadap $\mathrm{Y}$ (permintaan buah semangka di Kota Palangka Raya).

Jika $\mathrm{H}_{\mathrm{a}}$ diterima artinya secara parsial $\mathrm{X}_{1}$, $\mathrm{X}_{2}, \mathrm{X}_{3}, \mathrm{X}_{4}$ dan $\mathrm{X}_{5}$ berpengaruh nyata terhadap Y (permintaan buah semangka di Kota Palangka Raya).

\section{HASIL DAN PEMBAHASAN}

\section{Faktor-Faktor yang Mempengaruhi Permintaan Buah Semangka di Kota Palangka Raya}

Setelah diproses dengan menggunakan software SPSS maka hasil analisis faktor-faktor yang mempengaruhi permintaan buah semangka di Kota Palangka Raya dapat dilihat pada Tabel 5. 
Tabel 5. Analisis Regresi Faktor-faktor yang Mempengaruhi Permintaan Buah Semangka di Kota Palangka Raya

\begin{tabular}{|c|c|c|c|c|c|}
\hline \multicolumn{3}{|c|}{ Variabel } & $\begin{array}{c}\text { Koefisisien } \\
\text { Regresi }\end{array}$ & Standar Eror & $\begin{array}{c}\text { Signifikan } \\
\mathrm{T}\end{array}$ \\
\hline \multicolumn{3}{|l|}{ Constant } & 4,048 & 2,851 & 0,189 \\
\hline \multicolumn{3}{|c|}{ Harga Semangka (X1) } & $-0,474 * * *$ & 0,116 & 0,003 \\
\hline \multicolumn{3}{|c|}{ Harga Pepaya (X2) } & $0,412^{*}$ & 0,218 & 0,091 \\
\hline \multicolumn{3}{|c|}{ Harga Pisang (X3) } & $0,310 * *$ & 0,139 & 0,053 \\
\hline \multicolumn{3}{|c|}{ Pendapatan Perkapita (X4) } & $0,379 * *$ & 0,160 & 0,042 \\
\hline \multicolumn{3}{|c|}{ Jumlah Penduduk (X5) } & $-0,300 \mathrm{~ns}$ & 0,717 & 0,686 \\
\hline$\overline{\mathrm{R}^{2}}$ & & $0,967^{\mathrm{a}}$ & Sig $t=0,003, \operatorname{tar}$ & rcayaan $=99$, & \\
\hline $\mathrm{R}$-Square & & 0,936 & Sig $\mathrm{t}=0,091$, tar & rcayaan $=90$ & \\
\hline F hitung & & 26,109 & $\operatorname{Sig} \mathrm{t}=0,053, \operatorname{tar}$ & rcayaan $=94$, & \\
\hline F tabel $(99 \%)$ & $=$ & 6,06 & $\operatorname{Sig} \mathrm{t}=0,042, \operatorname{tar}$ & rcayaan $=95$, & \\
\hline Darbin Watson & $=$ & 2,391 & & & \\
\hline
\end{tabular}

Sumber: Data primer yang diolah

Dari hasil analisis data maka persamaan yang regresi yang didapat adalah sebagai berikut:

$$
\begin{gathered}
\mathrm{Y}=8,178+\mathrm{X}_{1}^{-0,474}+\mathrm{X}_{2}{ }^{0,412}+\mathrm{X}_{3}^{0,310}+ \\
\mathrm{X}_{4}{ }^{0,379}+\mathrm{X}_{5}^{-0,300}
\end{gathered}
$$

Untuk mempermudahkan penghitungan dan pendugaan terhadap persamaan tersebut diubah menjadi bentuk logaritma natural (ln), sehingga diperoleh sebagai berikut:

$$
\begin{gathered}
\ln Y=4,048-0,474 \operatorname{In} X_{1}+0,412 \operatorname{In} X_{2}+ \\
0,310 \operatorname{In} X_{3}+0,379 \operatorname{In} X_{4}-0,300 \operatorname{In} X_{5}
\end{gathered}
$$

Dari persamaan ini dapat diartikan bahwa apabila seluruh variabel bebas yaitu, harga buah semangka, harga buah pepaya, harga buah pisang, pendapatan perkapita, dan jumlah penduduk bernilai 0 maka variabel terikat permintaan buah semangka naik sebesar 4,04 $\mathrm{Kg}$.

\section{Uji Statistik}

\section{Koefisien Determinasi $\left(\mathbf{R}^{2}\right)$}

Koefisien determinasi digunakan untuk menguji goodness-fit dari model regresi yang dapat dilihat dari nilai $R$ Square. Untuk mengetahui perkembangan permintaan buah semangka di Kota Palangka Raya yang disebabkan oleh beberapa faktor antara lain yaitu harga buah semangka, harga buah pepaya, harga buah pisang, pendapatan perkapita dan jumlah penduduk dapat dilihat melalui besarnya nilai Koefisisen Determinasi $\left(\mathrm{R}^{2}\right)$ yang dapat dilihat pada Tabel 5 nilai $\mathrm{R}$ Square sebesar 0,936 yang artinya 93,6\% variasi variabel permintaan buah semangka telah dapat dijelaskan oleh harga buah semangka, harga buah pepaya, harga buah pisang, pendapatan perkapita dan jumlah penduduk. Sedangkan $6,4 \%$ dipengaruhi oleh variabel lain yang tidak dimasukkan kedalam model estimasi ini.

\section{Uji F-Statistik}

Uji F digunakan untuk mengetahui apakah variabel bebas yang diteliti secara bersama-sama berpengaruh terhadap variasi permintaan buah semangka di Kota Palangka Raya. Dalam penelitian ini dapat dilihat pada Tabel 6 .

Tabel 6. ANOVA Regresi linear Berganda

\begin{tabular}{ccccccc}
\hline & Model & Sum of Squares & Df & Mean Square & F & Sig. \\
\hline 1 & Regression & 0,129 & 5 & 0,026 & 26,109 & $0,000^{\mathrm{b}}$
\end{tabular}




\begin{tabular}{lccc} 
Residual & 0,009 & 9 & 0,001 \\
Total & 0,138 & 14 & \\
\hline
\end{tabular}

a. Dependent Variable: Permintaan Semangka

b. Predictors: (Constant), Jumlah Penduduk, Harga Pepaya, Harga Pisang, Harga Semangka, Pendapatan Perkapita

Berdasarkan Tabel 6, hasil perhitungan Program SPSS di atas, nilai $\mathrm{F}_{\text {hitung }}=26,109$ lebih besar dari nilai $\mathrm{F}_{\text {tabel }}=$ 6,06 pada taraf kepercayaan 99\%, sehingga $\mathrm{H}_{0}$ ditolak dan $\mathrm{H}_{\mathrm{a}}$ diterima. Artinya variabel bebas yaitu harga buah semangka, harga buah pepaya, harga buah pisang, pendapatan perkapita dan jumlah penduduk dalam model secara bersama-sama berpengaruh nyata terhadap variabel terikat yaitu permintaan buah semangka di Kota Palangka Raya atau variabel terikat permintaan buah semangka di Kota Palangka Raya dapat dijelaskan oleh variabel bebas harga buah semangka, harga buah pepaya, harga buah pisang, pendapatan perkapita dan jumlah penduduk.

\section{Uji Parsial (Uji-t Statistik)}

Uji parsial atau disebut juga uji-t adalah uji yang digunakan untuk mengetahui pengaruh variabel bebas yang diteliti secara individual terhadap permintaan buah semangka di Kota Palangka Raya. Dalam penelitian ini uji-t dapat dilihat pada Tabel 7.

Tabel 7. Coefficients Regresi Linear Berganda

\begin{tabular}{|c|c|c|c|c|c|}
\hline \multirow[t]{2}{*}{ Model } & \multicolumn{2}{|c|}{$\begin{array}{c}\text { Unstandardized } \\
\text { Coefficients }\end{array}$} & \multirow{2}{*}{$\begin{array}{c}\text { Standardized } \\
\text { Coefficients } \\
\text { Beta }\end{array}$} & \multirow[t]{2}{*}{$\mathrm{t}$} & \multirow[t]{2}{*}{ Sig. } \\
\hline & $\mathrm{B}$ & Std. Error & & & \\
\hline (Constant) & 4,048 & 2,851 & & 1,420 & 0,189 \\
\hline Harga Semangka & $-0,474$ & 0,116 & $-0,867$ & -4090 & 0,003 \\
\hline Harga Pepaya & 0,412 & 0,218 & 0,705 & 1,890 & 0,091 \\
\hline Harga Pisang & 0,310 & 0,139 & 0,574 & 2,223 & 0,053 \\
\hline Pendapatan Perkapita & 0,379 & 0,160 & 0,634 & 2,370 & 0,042 \\
\hline Jumlah Penduduk & $-0,300$ & 0,717 & $-0,204$ & $-0,418$ & 0,686 \\
\hline
\end{tabular}

a. Dependent Variable: Permintaan Semangka

\section{a. Harga Buah Semangka $\left(X_{1}\right)$}

Dari hasil analisis yang ditampilkan pada Tabel 7, dapat dilakukan uji-t dengan melihat nilai signifikansi $\mathrm{t}$ variabel harga buah semangka $\left(\mathrm{X}_{1}\right)$ terhadap permintaan buah semangka adalah sebesar 0,003 $\leq \alpha$ $(0,05)$. Hal ini dapat disimpulkan, bahwa variabel bebas yaitu harga buah semangka secara parsial berpengaruh nyata terhadap variabel terikat yaitu permintaan buah semangka di Kota Palangka Raya pada taraf kepercayaan 99\%. Dari hasil regresi dapat disimpulkan bahwa hasil ini sesuai dengan hipotesis penelitian yang ditetapkan dimana variabel harga buah semangka secara parsial berpengaruh nyata terhadap permintaan buah semangka di Kota
Palangka Raya. Berdasarkan persamaan regresi yang diperoleh, variabel harga buah semangka secara parsial berpengaruh nyata terhadap permintaan buah semangka, dapat dilihat nilai variabel $\mathrm{X}_{1}$ yaitu harga buah semangka bertanda negatif (-) sebesar 0,474 . Hal ini menunjukkan bahwa variabel harga buah semangka memiliki hubungan yang terbalik dengan permintaan buah semangka. Jika harga buah semangka naik sebesar 1 maka akan menyebabkan permintaan buah semangka turun sebesar $0,474 \%$, begitu juga sebaliknya. Dari hasil analisis ini sesuai dengan hukum permintaan yang menyatakan bahwa semakin rendah harga suatu komoditi maka jumlah yang akan diminta untuk komoditi 
tersebut akan semakin besar, dengan asumsi variabel yang lain tetap dan berlaku sebaliknya.

\section{b. Harga Buah Pepaya $\left(\mathbf{X}_{2}\right)$}

Berdasarkan analisis uji-t yang ditampilkan pada Tabel 7, dapat diketahui nilai signifikansi $\mathrm{t}$ variabel harga buah pepaya $\left(\mathrm{X}_{2}\right)$ terhadap permintaan buah semangka adalah sebesar 0,091, artinya variabel bebas yaitu harga buah pepaya $\left(\mathrm{X}_{2}\right)$ secara parsial berpengaruh nyata terhadap variabel terikat yaitu permintaan buah semangka di Kota Palangka Raya pada taraf kepercayaan 90\%. Variabel harga buah pepaya memiliki nilai koefisien regresi sebesar 0,412. Nilai positif menunjukkan bahwa harga buah pepaya mempunyai hubungan yang sebanding terhadap permintaan buah semangka di Kota Palangka Raya. Hal ini berarti bila terjadi kenaikan harga buah pepaya sebesar $1 \%$ maka permintaan buah semangka akan mengalami kenaikan sebesar $0,412 \%$.

\section{c. Harga Buah Pisang $\left(\mathbf{X}_{3}\right)$}

Berdasarkan analisis uji-t dengan melihat nilai signifikansi $\mathrm{t}$ variabel harga buah pisang terhadap permintaan buah semangka di Kota Palangka Raya adalah sebesar 0,053, artinya variabel bebas yaitu harga buah pisang $\left(\mathrm{X}_{3}\right)$ secara parsial berpengaruh nyata terhadap variabel terikat yaitu permintaan buah semangka di Kota Palangka Raya pada taraf kepercayaan 90\%. Dari hasil regresi dapat disimpulkan bahwa hasil ini sesuai dengan hipotesis penelitian yang ditetapkan dimana variabel harga buah pisang secara parsial berpengaruh nyata terhadap permintaan buah semangka di Kota Palangka Raya. Berdasarkan persamaan regresi yang diperoleh dapat dilihat nilai variabel $\mathrm{X}_{3}$ yaitu harga buah pisang bertanda positif $(+)$ sebesar 0,310. Hal ini menunjukan bahwa setiap adanya kenaikan harga buah pisang sebesar $1 \%$ maka akan terjadi kenaikan permintaan buah semangka sebesar $0,310 \%$.

\section{d. Pendapatan Perkapita $\left(\mathbf{X}_{4}\right)$}

Dari hasil analisis uji-t yang ditampilkan pada Tabel 7, dapat diketahui bahwa pendapatan perkapita $\left(\mathrm{X}_{4}\right)$ dengan nilai signifikasinya $\mathrm{t}$ sebesar $0,042<\alpha$ $(0,05)$. Hal ini menunjukan bahwa $\mathrm{H}_{0}$ ditolak atau $\mathrm{H}_{\mathrm{a}}$ diterima, artinya variabel bebas yaitu pendapatan perkapita secara parsial berpengaruh nyata terhadap variabel terikat yaitu permintaan buah semangka di Kota Palangka Raya. Variabel pendaptan perkapita memiliki nilai koefisien regresi sebesar 0,379 . Nilai positif $(+)$ menunjukan bahwa pendapatan penduduk mempunyai hubungan yang berbanding lurus terhadapa permintaan buah semangka di Kota Palangka Raya. Hal ini berarti apabila terjadi kenaikan pendapatan penduduk sebesar $1 \%$ maka permintaan buah semangka akan mengalami kenaikan sebesar $0,379 \%$

\section{e. Jumlah Penduduk $\left(\mathrm{X}_{5}\right)$}

Berdasarkan hasil analisis yang ditampilkan pada Tabel 3.3 dapat dilakukan uji-t dengan melihat nilai signifikansi $\mathrm{t}$ variabel jumlah penduduk $\left(\mathrm{X}_{5}\right)$ adalah sebesar $0,686>\alpha(0,05)$. Hal ini menunjukan bahwa $\mathrm{H}_{0}$ diterima atau $\mathrm{H}_{\mathrm{a}}$ ditolak, artinya variabel bebas yaitu jumlah penduduk secara parsial tidak berpengaruh nyata terhadap variabel terikat yaitu permintaan buah semangka di Kota Palangka Raya. Hasil ini tidak sesuai dengan hipotesis penelitian yang ditetapkan dimana jumlah penduduk secara parsial berpengaruh nyata terhadap permintaan buah semangka di Kota Palangka Raya. Jumlah penduduk dari hasil analisis ini tidak berpengaruh besar pada permintaan buah semangka karena penduduk yang semakin banyak belum tentu meningkatkan permintaan buah semangka di Kota Palangka Raya karena masyarakat di Kota Palangka Raya lebih mempertimbangkan harga buah semangka tersebut sebelum memutuskan untuk membeli buah semangka. Variabel jumlah penduduk memiliki nilai koefisien regresi sebesar 0,300. Nilai negatif menunjukan bahwa 
jumlah penduduk mempunyai hubungan yang tidak sebanding lurus terhadap permintaan buah semangka di Kota Palangka Raya. Hal ini berarti apabila terjadi kenaikan jumlah penduduk sebesar 1 $\%$ maka permintaan buah semangka akan mengalami penurunan sebesar $-0,300 \%$.

\section{KESIMPULAN DAN SARAN}

\section{Kesimpulan}

Berdasarkan hasil penelitian yang telah dilakukan, maka dapat disimpulkan sebagai berikut:

1. Hasil analisis bahwa nilai koefisien determinasi sebesar 0,936, artinya sebesar 93,6\% permintaan buah semangka di Kota Palangka Raya dipengaruhi oleh harga buh semangka, harga buah papaya, haga buah pisang, pendapatan per kapita dan jumlah penduduk.

2. Hasil dari uji $F$ menunjukkan nilai $F_{\text {hitung }}=26,109$ lebih besar dari nilai $\mathrm{F}_{\text {tabel }}=6,06$ pada taraf kepercayaan $99 \%$, sehingga faktor-faktor yang diujikan secara bersama-sama berpengaruh nyata terhadap permintaan buah semangka di Kota Palangka Raya.

3. Secara parsial harga buah semangka, harga buah pepaya, harga buah pisang dan pendapatan penduduk berpengaruh nyata terhadap permintaan buah semangka di Kota Palangka Raya yaitu pada taraf kepercayaan 90\%-99\%. Sedangkan faktor jumlah penduduk tidak berpengaruh pada taraf kepercayaan $95 \%$.

\section{Saran}

Berdasarkan kesimpulan di atas, maka disarankan:

1. Kepada Pemerintah Kota Palangka Raya dapat memperhatikan pendistribusian buah semangka sehingga dapat dikelola dengan baik sehingga kebutuhan pasar dapat terpenuhi.

2. Kepada pedagang agar memperhatikan pemasaran buah semangka sehingga tidak terjadi kekurangan dalam pemenuhan kebutuhan buah semangka.

3. Kepada kalangan akademis agar penelitian ini diharapkan dapat menjadi bahan acuan penelitian di Kota Palangka Raya.

\section{DAFTAR PUSTAKA}

Badan Pusat Statistik Provinsi Kalimantan Tengah. (2017). Kalimantan Tengah Dalam Angka 2017. Pertumbuhan Produktivitas Buah-Buahan Semusim di Kalimantan Tengah 2014-2016. Palangka Raya: Badan Pusat Statistik Provinsi Kalimantan Tengah.

(2017). Kalimantan Tengah Dalam Angka 2017. Luas Panen, Produksi dan Produktivitas Semangka Menurut Kabupaten/Kota Tahun 2016. Palangka Raya: Badan Pusat Statistik Provinsi Kalimantan Tengah. . (2017). Kalimantan Tengah Dalam Angka 2017. Tingkat Produksi dan Konsumsi Buah Semangka di Kota Palangka Raya Tahun 2016. Palangka Raya: Badan Pusat Statistik Provinsi Kalimantan Tengah.

Baga, K.M. (2008). Bertanam Semangka. Jakarta: Penebar Swadaya.

Gujarati, Damodar. (1997). Ekonometrika Dasar. Jakarta: Erlangga.

Jaya, Mungka. (2016). Prospek dan Perkembangan Semangka (http://budidaya pertan.blogspot.co.id). Diakses pada tanggal 18 Maret 2018.

Setiawan dan Kursini, D. E. (2010). Ekonometrika. Yogyakarta: CV. Andi Offset.

Siregar. (2010). Budidaya Semangka Panen 60 Hari. Jakarta: Penebar Swadaya. 